\title{
Effect of nitrogen management using leaf colour chart (LCC) on growth, yield attributes and yield in transplanted rice (Oryza sativa L.)
}

BHUPENDER SINGH AND P. K. SHARMA

Received : 19.03.2016; Revised : 10.04.2016; Accepted : 06.05.2016

MEMBERS OF RESEARCH FORUM:

Corresponding author : BHUPENDER SINGH, Krishi Vigyan Kendra, KHEDA (GUJARAT) INDIA
Co-authors :

P. K. SHARMA, Krishi Vigyan Kendra, KHEDA (GUJARAT) INDIA

\section{Summary}

A field experiment on rice (cv. GURJARI) was conducted during 2013-14 to 2015-16. The study was conducted by Krishi Vigyan Kendra, Kheda to compare the farmer's practices of application of $\mathrm{N}$ fertilizer with $\mathrm{N}$ fertilizer application as per leaf colour chart .The $\mathrm{N}$ fertilizer application as leaf colour chart recorded superior in growth and yield attributes as compared to farmer's practices. The grain yield was recorded $47.7 \mathrm{q} /$ ha and net income and B:C ration recorded Rs. 25950 /ha and 1:1.69 on pooled basis in $\mathrm{N}$ application as per LCC. The $\mathrm{N}$ save over farmer practices was recorded 48.8 per cent.

Key words : Leaf colour chart, Rice, Nitrogen management, Yield, Economics

How to cite this article : Singh, Bhupender and Sharma, P. K. (2016). Effect of nitrogen management using leaf colour chart (LCC) on growth, yield attributes and yield in transplanted rice (Oryza sativa L.). Asian J. Soil Sci., 11 (1) : 151-154 : DOI : 10.15740/HAS/AJSS/11.1/151-154. 